\title{
GENETIC DIVERSITY OF TWO INTRODUCED APHID SPECIES IN NEW ZEALAND
}

\author{
D. NICOL, K.F. ARMSTRONG, S.D. WRATTEN, P. WALSH ${ }^{1}$, \\ C.M. CAMERON, C. LAHMANN and C. FRAMPTON ${ }^{2}$
}

\author{
Dept of Entomology and Animal Ecology, P.O. Box 84, \\ Lincoln University, Canterbury. \\ ${ }^{1}$ Forest Research Institute, Private Bag 3020, Rotorua. \\ ${ }^{2}$ Centre for Computing \& Biometrics, P.O. Box 84, \\ Lincoln University, Canterbury.
}

\begin{abstract}
The rose-grain aphid (Metopolophium dirhodum Walker) and green spruce aphid (Elatobium abietinum Walker) were both accidentally introduced into New Zealand. The former colonises barley predominantly, while the latter feeds on spruces (Picea spp.). RAPD-PCR DNA methods were used to determine the genetic diversity within each species. The genetic variation detected in New Zealand and UK populations was significantly lower for the green spruce aphid than for the rose-grain aphid. In New Zealand, this could be caused by fewer introductions and restricted host-plant availability for the green spruce aphid.
\end{abstract}

Keywords: Elatobium abietinum, Metopolophium dirhodum, DNA analysis, genetic diversity, geographic variation

\section{INTRODUCTION}

Introduced insect species can be a significant problem to agriculture and forestry in New Zealand. In the absence of chemical control, the rose-grain aphid (Metopolophium dirhodum) caused estimated cereal yield losses of \$NZ 0.3-5 million per year in New Zealand (Grundy 1990). However, in 1985 the aphid parasitoidAphidius rhopalosiphi De Stefani-Perez (Hymenoptera: Aphidiidae) was imported and released as a potential control agent. This introduction led to a high degree of parasitism of $M$. dirhodum in 1987-89 with a suggested decline in its pest status (Farrell and Stufkens 1990). The green spruce aphid (Elatobium abietinum) is a serious defoliator of Sitka spruce (Picea sitchensis Bong.) and is a major barrier preventing spruce being used as a production forest species in New Zealand (Miller and Knowles 1989).

In the UK, $M$. dirhodum is native and has asexual and sexual stages, whereas although E. abietinum was first recorded in 1846 it may have been introduced with Norway spruce (Picea abies L.) before 1500 and sexual populations occur rarely (Carter and Austara 1994). In New Zealand, M. dirhodum was first found in 1981 (Burnett 1984), with sexual forms reported very rarely (Stufkens and Farrell 1985; Farrell unpubl.).E. abietinum was first found in New Zealand in 1920 and no sexual stages have been found here (Zondag 1983).

An analysis of the temporal and spatial genetic variation of an introduced pest can help understand and predict its relative "fitness" in a new environment (De Barroet al. 1995; Armstrong and Wratten 1996). The use of randomly amplified polymorphic DNA with the polymerase chain reaction (RAPD-PCR) has proved a useful tool in assessing insect genetic diversity and its value in the analysis of these two introduced aphid species was assessed in this paper.

\section{Field sampling}

\section{METHOD}


M. dirhodum populations were sampled from a winter wheat field at Lincoln, Canterbury using a McCullogh Super Air Stream IV garden blower/vac. Ten samples, each over an area of $5 \mathrm{~m} \times 0.5 \mathrm{~m}$, were taken at distances from the south end of the paddock of 0-5 m, 10-15 m, 20-25 m, 40-45 m, 60-65 m, 80-85 m, 100-105 m, 140-145 $\mathrm{m}, 180-185 \mathrm{~m}$ and $220-225 \mathrm{~m}$ on each of 4 parallel transects at 20, 40, 120 and $160 \mathrm{~m}$ from the east end of the paddock, totalling 40 samples in all. M. dirhodum was also collected from a winter wheat field in Invergowrie, Scotland. Aphids were collected by hand from plants that were at least $10 \mathrm{~m}$ apart from each other. These aphids were sent to New Zealand in $96 \%$ ethanol for subsequent DNA analysis.

E. abietinum was collected by removing shoots from Sitka spruce at six sites in New Zealand, up to $1000 \mathrm{~km}$ apart. These sites were Rotorua, Whakarewrewa, Hororata, Mamaku, Mahinapoua and Dunedin. A total of 40 aphids sampled from 22 different Sitka spruce trees, were compared with 40 aphids collected from four locations in the UK, up to $420 \mathrm{~km}$ apart.

All aphids of both species were screened for parasitoids (Nicolet al. 1997) except for spruce aphids in New Zealand, which have no known parasitoids.

\section{DNA analysis}

DNA was extracted according to Nicol et al. (1997). Four RAPD-PCR methods were used, two for each species.M. dirhodum was analysed using single 10-mer random primers and either method A)Taq polymerase, followed by agarose gel electrophoresis; or B) Stoffel polymerase, followed by polyacrylamide gel electrophoresis (Nicol et al. 1997).

E. abietinum was analysed using PCR reaction mixtures of $10 \mu 1$ consisting of 1.2 x Taq buffer, 0.5 unit of Taq polymerase (Boehringer Manheim), $2 \mathrm{mM} \mathrm{MgCl} 2,0.15$ $\mathrm{mM}$ dNTP, $0.25 \mathrm{mM}$ of each primer and 2 - $4 \mathrm{ng}$ of aphid DNA. Amplifications were carried out in a Perkin-Elmer 2400 thermocycler using a regime of $94^{\circ} \mathrm{C}$ for $2 \mathrm{~min}$, and then 10 cycles of $94^{\circ} \mathrm{C}$ for $15 \mathrm{~s}, 48^{\circ} \mathrm{C}$ for $30 \mathrm{~s}$ and $68^{\circ} \mathrm{C}$ for $3 \mathrm{~min}$. This was followed by 26 cycles of $94^{\circ} \mathrm{C}$ for $15 \mathrm{~s}, 48^{\circ} \mathrm{C}$ for $30 \mathrm{~s}$ and $68^{\circ} \mathrm{C}$ for $3 \mathrm{~min}$ (extended by a further 20 seconds each cycle), then a final extension period of $72^{\circ} \mathrm{C}$ for $7 \mathrm{~min}$ before samples were cooled to $10{ }^{\circ} \mathrm{C}$. Method $\mathrm{C}$ used two 10-mer random primers (OPA2 5'TGCCGAGCTG 3') and (OPK7 5'AGCGAGCAAG3'). Method D used 18-mer(18f 5'ACTGGCAGGATCAACCAG3') and 22-mer (28a 5'GAACGTGAGCTGGGTTTAGACC3') universal primers originally designed to amplify the IGS region of rDNA.

For each E. abietinum sample, $5 \mu 1$ of RAPD products was resolved by submerged gel electrophoresis using a $1 \%$ agarose gel containing ethidium bromide $(0.08 \mathrm{mg} / \mathrm{ml})$ in $0.5 \mathrm{x}$ TBE. This was run for $1 \mathrm{~h}$ at $4.5 \mathrm{~V} / \mathrm{cm}$ against a $100 \mathrm{bp}$ ladder (Gibco BRL). A Polaroid picture was taken as a permanent record.

\section{Statistical analysis}

The Jaccard similarity index $(S)$ (Sneath and Sokal 1983) was used to compare aphid populations based on the presence or absence of RAPD bands. In this analysis, $S=1$ if all bands are shared by all individuals, but $S=0$ if no bands are shared. $S$ was compared statistically using the non-parametric Mann-Whitney $U$ test.

Calculation of a 'NZ/UK' index (given below) measured the relative genetic variation in New Zealand to that in the UK, for each species sampled. Aphids with the same RAPD banding pattern were designated as being of the same 'clone' $\chi^{2}$ analysis was used to compare the indices statistically.

$$
\begin{aligned}
& \text { number of 'clones' in NZ sample x number of aphids in UK sample } \\
& \text { NZ/UKindex }=\frac{\text { number of 'clones' in UK sample number of aphids in NZ sample }}{\text { nom }}
\end{aligned}
$$

\section{RESULTS}

The most discriminating RAPD-PCR analyses distinguished between every $M$. dirhodum individual in the UK sample and 28 of 40 (70\%) of E. abietinum from the UK (Table 1). In the New Zealand samples $85.7 \%$ of M. dirhodum, but noE. abietinumwere distinguished (Table 1). This difference in genetic differentiation between the two 
species was supported by a lower $S$ value $\left(\chi^{2}>905.41, P<0.001\right)$ and higher 'NZ/UK' index $\left(\mathrm{c}^{2}>43.89, P<0.001\right)$ for $M$. dirhodum than for $E$. abietinum (Table 1$)$.

Different RAPD-PCR methods suggested significantly different levels of genetic variation $\left(S\right.$ values) within the same samples $\left(\chi^{2}>54.02, P<0.001\right.$; Table 1$)$.

TABLE 1: The number of 'clones' and the Jaccard similarity index of populations of $M$. dirhodum and E. abietinum from the UK and New Zealand.

\begin{tabular}{lccccc}
\hline Population & $\begin{array}{c}\text { RAPD } \\
\text { method }^{2}\end{array}$ & $\begin{array}{c}\text { Number } \\
\text { of clones } \\
\text { identified }\end{array}$ & $\begin{array}{c}\text { Number } \\
\text { of aphids } \\
\text { analysed }\end{array}$ & $\begin{array}{c}\text { NZ/UK } \\
\text { index }\end{array}$ & $\begin{array}{c}\text { Jaccard } \\
\text { index } \\
(S)\end{array}$ \\
\hline NZ $M . d$ & A & 3 & 35 & 0.771 & $0.637(595)$ \\
UK $M . d$ & A & 4 & 36 & - & $0.827(630)$ \\
NZ $M . d$ & B & 30 & 35 & 0.857 & $0.292(595)$ \\
UK $M . d$ & B & 36 & 36 & - & $0.266(630)$ \\
NZ $M . d$ & A\&B & 30 & 35 & 0.857 & $0.353(595)$ \\
UK $M . d$ & A\&B & 36 & 36 & - & $0.375(630)$ \\
NZ $E . a$ & C & 1 & 40 & 0.071 & $1.000(780)$ \\
UK $E . a$ & C & 14 & 40 & - & $0.678(780)$ \\
NZ $E . a$ & D & 1 & 40 & 0.063 & $1.000(780)$ \\
UK $E . a$ & D & 16 & 40 & - & $0.781(780)$ \\
NZ $E . a$ & C\&D & 1 & 40 & 0.036 & $1.000(780)$ \\
UK $E . a$ & C\&D & 28 & 40 & - & $0.716(780)$ \\
\hline
\end{tabular}

${ }^{1}$ M. $d=$ Metopolophium dirhodum, E. $a=$ Elatobium abietinum.

${ }^{2}$ Where two methods are stated, RAPD bands have been accumulated from the two separately run methods (see DNA analysis in Method section).

${ }^{3}$ Numbers in parentheses are the number of comparisons made.

\section{DISCUSSION}

There are significant differences in intraspecific genetic diversity between UK and New Zealand populations of M. dirhodum (Nicol et al. 1997) and E. abietinum (Nicol et al. unpubl. data). The results here show that there is also a difference in the level of genetic variation between the two species studied.

In the USA, a lower genetic diversity has been shown for the Russian wheat aphid (Diuraphis noxia Mordvilko), than for the greenbug (Schizaphis graminum Rondani) and is probably due to the much later introduction of, and the lack of sexual phase for $D$. noxia (Shufranet al. 1991; 1997). However, in the current research the genetic variation of E. abietinum was significantly lower than that of $M$. dirhodum in New Zealand, yet E. abietinum was introduced earlier and sexuals of both species are thought to be either very rare or non-existent in this country. Founder effects and genetic drift are the most probable causes for this difference. Founder effects can be interpreted as the number, diversity and success of individual aphids introduced into New Zealand. Genetic drift is affected by the success of these initial introduced individuals and the random changes in gene frequencies associated with small populations caused by differences in aphid mobility, host-plant availability and genetic diversity, mortality and fitness. Specifically, the most plausible explanation for the difference in genetic diversity between the two species studied is that the number of introductions was significantly lower and/or that the host-plant availability and genetic diversity was much more restrictive for E. abietinum, thereby creating greater selection pressure. The host-plant range for E. abietinum in New Zealand encompasses P. sitchensis and P. abies (Zondag 1983), which are found in isolated pockets and are propagated from a limited number of seed sources and provenances (Miller and Knowles 1989). In contrast, M. dirhodum feeds on a wide range of host-plants including the Gramineae: wheat, oats, barley, rye, maize, prairie grass (Bromus catharticus L.), cocksfoot (Dactylis glomerata L.), Kentucky bluegrass (Poa 
pratensis L.), and Phalaris spp, as well as Rosaceae as an overwintering host for the holocyclic generation in Europe. These plants are available over a wide geographic area in New Zealand (Stufkens and Farrell 1985).

The RAPD-PCR protocols used in the current research allow an interspecific comparison of genetic variation in New Zealand aphid populations via the NZ/UK index, i.e., the extent of variation in New Zealand as compared to that in the UK for the same species. However, in the UK aphid populations studied, the higher genetic variation recorded for $M$. dirhodum may have been due to the different RAPD-PCR methods used for that species. As shown here, the different methods can suggest different levels of genetic diversity within the same samples (Table 1) as they highlight different regions of DNA. The use of an analytical technique that can compare DNA regions common to both species, e.g. the IGS region of rDNA, would aid in the interpretation of the current findings. This would allow easier interspecific comparisons of genetic variation, as has been recorded with other organisms (Avise and Aquadro 1982). Nevertheless, the genetic variation in E. abietinum in New Zealand is significantly restricted.

\section{ACKNOWLEDGEMENTS}

This research is supported by the Marsden Fund, administered by the Royal Society of New Zealand.

\section{REFERENCES}

Armstrong, K.A. and Wratten, S.D., 1996. The use of DNA analysis and the polymerase chain reaction in the study of introduced pests in New Zealand. Pp 231-263.In: The Ecology of Agricultural Pests: Biochemical Approaches. W.O.C. Symondson and J.E. Liddell (Eds), Chapman and Hall, London.

Avise, J.C. and Aquadro, C.F., 1982. A comparative summary of genetic distances in the vertebrates. J. Evol. Biol. 15: 151-185.

Burnett, P.A., 1984. Cereal crop pests. Pp 153-168. In: New Zealand Pests and Beneficial Insects. R.R. Scott (Ed); Lincoln University Press, Christchurch.

Carter, C. and Austara, O., 1994. The occurrence of males, oviparous females and eggs within anholocyclic populations of the green spruce aphid Elatobium abietinum (Walker) (Homoptera:Aphididae). Nor. J. Ento. 41: 53-58.

De Barro, P.J., Sherratt, T.N. and Maclean N., 1995. An investigation of the differential performance of clones of the aphidSitobion avenae on two host species.Oecologia 104: 379-385.

Farrell, J.A. and Stufkens, M.W., 1990. The impact of Aphidius rhopalosiphi (Hymenoptera: Aphidiidae) on populations of the rose grain aphid (Metopolophium dirhodum) (Hemiptera: Aphididae) on cereals in Canterbury, New Zealand. Bull. Ento. Res. 80: 377-383.

Grundy, T.P., 1990. A cost-benefit analysis of biological control of rose-grain aphid in New Zealand. Proc. 43rd N.Z. Weed and Pest Control Conf.: 163-165.

Miller, J.T. and Knowles F.B., 1989. Introduced forest trees in New Zealand: recognition, role and seed source. 6 . The spruces. FRI Bulletin No. 124: 20p.

Nicol, D., Armstrong K.F., Wratten S.D., Cameron C.M., Frampton C.M. and Fenton B., 1997. Genetic variation in an introduced aphid pest (Metopolophium dirhodum) in New Zealand and relation to individuals from Europe. Mol. Ecol. 6: 255-265.

Shufran, K.A., Black IV, W.C. and Margolies, D.C., 1991. DNA fingerprinting to study spatial and temporal distributions of an aphid, Schizaphis graminum (Homoptera: Aphididae). Bull. Ento. Res. 81: 303-313.

Shufran, K.A., Burd, J.D. and Webster, J.A., 1997. Biotypic status of Russian wheat aphid (Homoptera: Aphididae) populations in the United States.J. Econ. Ento. (in press).

Sneath, P.H.A. and Sokal, R.R., 1973. Numerical Taxonomy; the Principle and Practice of Numerical Classification. W.H. Freeman, San Francisco.

Stufkens, M.W. and Farrell, J.A., 1985. Observations on the phenology of the rose-grain aphids in mid-Canterbury. Proc. 38th N.Z. Weed and Pest Control Conf.: 184-187.

Zadoks, J.C., Chang, T.T. and Konzak, C.F., 1974. A decimal code for the growth stages 
of cereals. Weed Res. 14: 415-421.

Zondag, R., 1983. Elatobium abietinum (Walker) (Hemiptera: Aphididae) Spruce Aphid. Forest and Timber Insects in N.Z. No. 54: 4p. 